\title{
Administration of umbilical cord mesenchymal stem cells in patients with severe COVID-19 pneumonia
}

\author{
Zhinian Guo, Yunlong Chen, Xiaoyu Luo, Xiaolong He, Yong Zhang and Jiang Wang*
}

There are no specific drug therapies or vaccines for the pandemic of coronavirus disease 2019 (COVID-19), which is associated with substantial mortality. Attenuating or reversing the cytokine storm is critical for treating patients with severe COVID-19 pneumonia. Mesenchymal stem cells (MSCs) have been shown to have powerful immunoregulation and reparative properties in injured tissue with good safety [1]. This report aims to investigate whether umbilical cord MSC (UC-MSC) therapy improves the outcomes of 31 patients with severe or critical COVID-19 pneumonia.

We wish to report our experience using UC-MSCs for the treatment of severe COVID-19 pneumonia at Taikangtongji Hospital in Wuhan, China, from January 3, 2020, to April 4, 2020. Patient data, including demographics, clinical data, laboratory indices, treatment, and in-hospital outcomes, were collected. Severe acute respiratory syndrome coronavirus 2 (SARS-CoV-2) polymerase chain reaction (PCR) results of all patients were positive before UC-MSCs infused. Patients were diagnosed and treated according to national guidelines. Before the intravenous drip was established, UC-MSCs $\left(1 \times 10^{6}\right.$ cells per kilogram of weight) were suspended in $100 \mathrm{ml}$ normal saline. We report numbers (percentages) for categorical variables and the median (interquartile range [IQR]) or mean \pm standard deviation (SD) for continuous variables. Intergroup comparisons were performed with paired $t$ tests.

We treated 31 COVID-19 patients with UC-MSCs. The median age was 70 years (IQR, $61-71$ years); 25 patients $(80.6 \%)$ were male. The proportion of treatment

\footnotetext{
* Correspondence: 504641821@qq.com

Department of Cardiology, Xinqiao Hospital of Army Medical University, 183 Xinqiao Street, Chongqing 400037, China
}

with oxygen was the highest (31 [100\%]), followed by antivirals (26 [83.9\%]), antibiotics (23 [74.2\%]), intravenous immunoglobulin (8 [25.8\%]), intravenous albumin (8 [25.8\%]), and methylprednisolone (6 [19.4\%]). The median (IQR) volume of infused UC-MSCs was $200 \mathrm{~mL}$ $(100-300 \mathrm{~mL})$. No adverse events were attributable to intravenous transplantation of UC-MSCs. After the first infusion of UC-MSCs, the SARS-CoV-2 PCR results of 30 patients $(96.8 \%)$ became negative after a mean time of 10.7 days (SD, 4.2 days) (Table 1 ). Laboratory parameters tended to improve after UC-MSC therapy compared to the status before UC-MSC therapy, including elevated lymphocyte count (median [IQR], 1.09 [0.68-1.35] $\times 10^{9} /$ $\mathrm{L}$ vs $\left.1.43[1.02-2.20] \times 10^{9} / \mathrm{L} ; P<0.001\right)$, decreased $\mathrm{C}$ reactive protein level (median [IQR], 13.39 [1.30-38.86] $\mathrm{mg} / \mathrm{L}$ vs $0.50[0.50-6.40] \mathrm{mg} / \mathrm{L} ; P=0.003)$, decreased procalcitonin level (median [IQR], 0.07 [0.05-0.09] ng/ $\mathrm{mL}$ vs $0.04[0.03-0.06] \mathrm{ng} / \mathrm{mL} ; P<0.001)$, decreased interleukin-6 level (median [IQR], 13.78 [5.69-25.26] $\mathrm{pg} / \mathrm{mL}$ vs 4.86 [2.13-8.19] $\mathrm{pg} / \mathrm{mL} ; P<0.001)$, decreased D-dimer level (median [IQR], 495 [320-727] $\mathrm{ng} / \mathrm{mL}$ vs 288 [197-537] ng/mL; $P=0.010)$, and elevated $\mathrm{PaO}_{2} /$ $\mathrm{FiO}_{2}$ (median [IQR], 242 [200-294] vs 332 [288-364]; $P<0.001$ ) (Table 2).

Our experience showed that UC-MSC therapy may restore oxygenation and downregulate cytokine storms in patients hospitalized with severe COVID-19 without any infusion reaction. This approach is a promising candidate for the treatment of severe COVID-19 [2]. During the outbreak of COVID-19 in Wuhan, China, the number of patients increased sharply. However, the hospital capacity was limited, and many patients could not be admitted to the hospital. Hence, days between onset of symptoms and hospital admission were long. UC-MSCs can improve the lung microenvironment, pulmonary

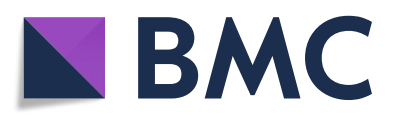

(c) The Author(s). 2020 Open Access This article is licensed under a Creative Commons Attribution 4.0 International License, which permits use, sharing, adaptation, distribution and reproduction in any medium or format, as long as you give appropriate credit to the original author(s) and the source, provide a link to the Creative Commons licence, and indicate if changes were made. The images or other third party material in this article are included in the article's Creative Commons licence, unless indicated otherwise in a credit line to the material. If material is not included in the article's Creative Commons licence and your intended use is not permitted by statutory regulation or exceeds the permitted use, you will need to obtain permission directly from the copyright holder. To view a copy of this licence, visit http://creativecommons.org/licenses/by/4.0/. The Creative Commons Public Domain Dedication waiver (http://creativecommons.org/publicdomain/zero/1.0/) applies to the data made available in this article, unless otherwise stated in a credit line to the data. 
Table 1 Baseline characteristics, treatments, and outcomes of patients with COVID-19 with UC-MSC therapy

\begin{tabular}{|c|c|}
\hline & Total $(n=31)$ \\
\hline \multicolumn{2}{|l|}{ Demographics and clinical characteristics } \\
\hline Age, median (IQR), years & $70(61-71)$ \\
\hline Sex, male & $25(80.6 \%)$ \\
\hline $\mathrm{BMl}$, mean $\pm \mathrm{SD}, \mathrm{kg} / \mathrm{m}^{2}$ & $24.5 \pm 2.9$ \\
\hline \multicolumn{2}{|l|}{ Symptoms at admission } \\
\hline Fever & $24(77.4 \%)$ \\
\hline Cough & $25(80.6 \%)$ \\
\hline Dyspnea & $17(54.8 \%)$ \\
\hline Chest congestion & $14(45.2 \%)$ \\
\hline Fatigue & $12(38.7 \%)$ \\
\hline \multicolumn{2}{|l|}{ Comorbidities } \\
\hline Hypertension & $13(41.9 \%)$ \\
\hline Chronic obstructive pulmonary disease & $6(19.4 \%)$ \\
\hline Coronary artery disease & $5(16.1 \%)$ \\
\hline Diabetes & $5(16.1 \%)$ \\
\hline \multicolumn{2}{|l|}{ Chest computed tomographic findings } \\
\hline Bilateral pneumonia & $31(100 \%)$ \\
\hline Multiple mottling/ground-glass opacity & $26(83.9 \%)$ \\
\hline \multicolumn{2}{|l|}{ Main complications } \\
\hline Respiratory failure & $10(32.3 \%)$ \\
\hline Acute respiratory distress syndrome & $8(25.8 \%)$ \\
\hline Cardiac injury & $12(38.7 \%)$ \\
\hline \multicolumn{2}{|l|}{ Disease severity status } \\
\hline Severe & $23(74.2 \%)$ \\
\hline Critical & $8(25.8 \%)$ \\
\hline $\begin{array}{l}\text { Days between onset of symptoms and } \\
\text { hospital admission, mean } \pm \mathrm{SD} \text {, days }\end{array}$ & $37.2 \pm 17.6$ \\
\hline $\begin{array}{l}\text { Days between onset of symptoms and } \\
\text { UC-MSC therapy, mean } \pm S D \text {, days }\end{array}$ & $50.7 \pm 12.6$ \\
\hline $\begin{array}{l}\text { Days between hospital admission and } \\
\text { UC-MSC therapy, median (IQR), days }\end{array}$ & $10.0(6.0-22.0)$ \\
\hline Intensive care unit admission & $16(51.6 \%)$ \\
\hline \multicolumn{2}{|l|}{ Treatments } \\
\hline Oxygen & $31(100 \%)$ \\
\hline Oxygen inhalation & 19 (61.3\%) \\
\hline Noninvasive mechanical ventilation & $4(12.9 \%)$ \\
\hline Invasive mechanical ventilation & $8(25.8 \%)$ \\
\hline Antivirals & $26(83.9 \%)$ \\
\hline Arbidol & $20(64.5 \%)$ \\
\hline Interferon alfa-2b & $9(29.0 \%)$ \\
\hline Oseltamivir & $3(9.7 \%)$ \\
\hline Chloroquine & $3(9.7 \%)$ \\
\hline Antibiotics & $23(74.2 \%)$ \\
\hline Methylprednisolone & $6(19.4 \%)$ \\
\hline
\end{tabular}

Table 1 Baseline characteristics, treatments, and outcomes of patients with COVID-19 with UC-MSC therapy (Continued)

\begin{tabular}{ll}
\hline & Total $(n=31)$ \\
\hline UC-MSC therapy & \\
UC-MSC volume, median (IQR), $\mathrm{mL}$ & $200(100-300)$ \\
Single infusion of UC-MSCS & $11(35.5 \%)$ \\
Two infusions of UC-MSCS & $9(29.0 \%)$ \\
Three infusions of UC-MSCs & $11(35.5 \%)$ \\
Intravenous immunoglobulin therapy & $8(25.8 \%)$ \\
Intravenous albumin therapy & $8(25.8 \%)$ \\
Outcomes & \\
SARS-CoV-2 clearance & $30(96.8 \%)$ \\
Discharged & $27(87.1 \%)$ \\
Death & $4(12.9 \%)$
\end{tabular}

UC-MSCS umbilical cord mesenchymal stem cells, IQR interquartile range, SD standard deviation, SARS-CoV-2 severe acute respiratory syndrome coronavirus 2

fibrosis, and lung function, probably due to the regulation of the inflammatory response and the promotion of tissue repair and regeneration [3]. A recent report of 7 patients found that bone marrow MSC therapy was an effective treatment for severe COVID-19 [3]. Moreover, another recent study indicated that bone marrow MSC therapy can improve hypoxia, immune reconstitution, and cytokine storms in patients with severe COVID-19 [4], which was consistent with our results. Further large multiple-center prospective trials are needed to confirm our results in the future.

Table 2 Comparison of laboratory parameters before and after UC-MSC therapy

\begin{tabular}{|c|c|c|c|}
\hline Characteristics & $\begin{array}{l}\text { Before UC-MSC } \\
\text { therapy }\end{array}$ & $\begin{array}{l}\text { After UC-MSC } \\
\text { therapy }\end{array}$ & $P$ value \\
\hline $\begin{array}{l}\text { White blood cell count, } \\
\times 10^{9} / \mathrm{mL} \text { (normal range, } \\
3.5-9.5 \text { ) }\end{array}$ & $6.72 \pm 2.62$ & $6.43 \pm 1.72$ & 0.346 \\
\hline $\begin{array}{l}\text { Lymphocyte count, } \\
\times 10^{9} / \mathrm{mL} \text { (normal range, } \\
1.1-3.2 \text { ) }\end{array}$ & $1.09(0.68-1.35)$ & $1.43(1.02-2.20)$ & $<0.001$ \\
\hline $\begin{array}{l}\text { C-reactive protein, mg/L } \\
\text { (normal range, }<10 \text { ) }\end{array}$ & $13.39(1.30-38.86)$ & $0.50(0.50-6.40)$ & 0.003 \\
\hline $\begin{array}{l}\text { Procalcitonin, } \mathrm{ng} / \mathrm{mL} \\
\text { (normal range, }<0.05 \text { ) }\end{array}$ & $0.07(0.05-0.09)$ & $0.04(0.03-0.06)$ & $<0.001$ \\
\hline $\begin{array}{l}\text { Interleukin-6, pg/mL } \\
\text { (normal range, }<7 \text { ) }\end{array}$ & $13.78(5.69-25.26)$ & $4.86(2.13-8.19)$ & $<.001$ \\
\hline $\begin{array}{l}\text { D-dimer, ng/mL } \\
\text { (normal range, < 243) }\end{array}$ & $495(320-727)$ & $288(197-537)$ & 0.010 \\
\hline $\mathrm{PaO}_{2} / \mathrm{FiO}_{2}$ & $242(200-294)$ & $332(288-364)$ & $<0.001$ \\
\hline
\end{tabular}

UC-MSCs umbilical cord mesenchymal stem cells, $\mathrm{PaO}_{2} / \mathrm{FiO}_{2}$ ratio ratio of the partial pressure of arterial oxygen to the percentage of inspired oxygen 


\section{Acknowledgements}

We thank all the medical staff of Taikangtongji Hospital for the diagnosis and treatment of patients with COVID-19.

\section{Authors' contributions}

Concept and design: JW and ZG. Acquisition, analysis, or interpretation of data: all authors. Drafting of the manuscript: JW and ZG. Critical revision of the manuscript for important intellectual content: JW. Statistical analysis: ZG. Administrative, technical, or material support: JW. Supervision: JW. All authors have read and approved the final manuscript.

\section{Funding}

None

\section{Availability of data and materials}

The data used to support the findings of this study are available from the corresponding author upon request.

\section{Ethics approval and consent to participate}

The Clinical Research Ethics Commissions of Taikangtongji Hospital approved the study and granted a waiver for the need to obtain written informed consent from the study participants as COVID-19 is an emerging infectious disease.

\section{Consent for publication}

Not applicable.

\section{Competing interests}

All authors declare no competing interests.

Received: 15 June 2020 Accepted: 1 July 2020

Published online: 11 July 2020

\section{References}

1. Galipeau J, Sensebe L. Mesenchymal stromal cells: clinical challenges and therapeutic opportunities. Cell Stem Cell. 2018;22(6):824-33.

2. Marini JJ, DeBacker D, Gattinoni L, Ince C, Martin-Loeches I, Singer P, Singer $M$, Westphal M, Vincent JL. Thinking forward: promising but unproven ideas for future intensive care. Crit Care. 2019;23(Suppl 1):197.

3. Leng Z, Zhu R, Hou W, Feng Y, Yang Y, Han Q, Shan G, Meng F, Du D, Wang $S$, et al. Transplantation of ACE2(-) mesenchymal stem cells improves the outcome of patients with COVID-19 pneumonia. Aging Dis. 2020;11(2): 216-28.

4. Sengupta V, Sengupta S, Lazo AJ, Woods P, Nolan A, Bremer N. Exosomes derived from bone marrow Mesenchymal stem cells as treatment for severe COVID-19. Stem Cells Dev. 2020.

\section{Publisher's Note}

Springer Nature remains neutral with regard to jurisdictional claims in published maps and institutional affiliations. 